\title{
Aboriginal military service and assimilation
}

\author{
Noah Riseman
}

In 1957, the Australian Broadcasting Corporation (ABC) Radio ran a 30-minute feature entitled 'The Story of Douglas Grant: The Black Scotsman'. The broadcast narrated the life of Douglas Grant, an Aboriginal man raised in a white Sydney family who served in the First World War. Brian Hungerford reported: 'It [Grant's story] means that if you take a newborn baby straight from its mother, you can bring it up to fit into any society at any level. There is no inherent mental or emotional difference between the primitive man and the civilised one'. ${ }^{1}$ How Douglas Grant's life sits as an assimilation narrative and the role of military service in that account is complex. Whereas the ABC and other media reports promoted Grant as a 'poster-child' for assimilation, by his death in 1951 the unfulfilled promises of equality left Grant questioning whether Australian society would ever allow Aboriginal people to assimilate.

Douglas Grant was not the only Aboriginal veteran touted as a model of assimilation, nor the only 'celebrity' used to promote assimilation. Especially during and after the Second World War, the media and policymakers endorsed the armed forces as a possible way to promote Aboriginal assimilation because of the links between military service and duties of citizenship. Indigenous servicemen and women themselves also saw the military as an opportunity to earn citizenship rights. Many Indigenous service members found equality in the armed forces. Their experiences support military sociologists' arguments that the military-socialisation process aims to train service personnel with a mentality of sameness and conformity, breaking down racial and ethnic barriers. ${ }^{2}$ When many Indigenous service personnel returned to civilian life, they sought continuing equality through embracing assimilation. They encountered the same prejudices as many other Indigenous Australians, gradually leading Indigenous ex-service personnel, too, to question whether assimilation brought equality. The complex links among government, media and Indigenous attitudes therefore situate military service as a critical but overlooked component of the history of assimilation in Australia.

Several thousand Aboriginal and Torres Strait Islander people served in the armed forces from the Boer War through the Vietnam War. At least 50 served in the Boer War, over 800 in the First World War, over 4,000 in the Second World War and at least 350 in Korea, Malaya and Vietnam. Across testimonies and writings of ex-servicemen and women from these conflicts are common patterns:

1 'The Story of Douglas Grant, the Black Scotsman' 1957.

2 Wadham 2013: 229. See also Riseman 2013a. 
childhoods confronting discrimination, the armed forces representing a site of equality and empowerment, upon return to civilian life desiring to live as equals whilst non-Indigenous Australians continued to practice de jure and de facto discrimination. ${ }^{3}$ This article focuses on three specific Aboriginal veterans as case studies: Douglas Grant from the First World War, Reg Saunders from the Second World War and Korea, and Phil Prosser from Vietnam. Unlike most veterans, these men had profiles in the media as supposed assimilation 'success' stories. Yet in common with many other Indigenous veterans, military service was central in their lives, and after their military service they lived and worked in mainstream white Australia. These and many other Indigenous service personnel simply sought equality; the military did allow them to experience true equality, and they hoped that through embracing assimilation they could continue to live as equals. Media and governments picked up on these particular men's life stories and identified the armed forces as a site to promote assimilation. Yet in civilian life these and other ex-servicemen and women frequently confronted the shortcomings of assimilation, including discrimination in employment, housing and in their interactions with white Australians. As time went on the prejudice they encountered frustrated them, and as public discourses about assimilation shifted, so too did these ex-service personnel re-evaluate their positions and embrace integration and self-determination as true harbingers of equality.

Assimilation(ism) has multiple connotations. Although historians Tim Rowse and John Maynard argue that assimilation practices began in 1788, assimilation as an agenda entered popular discourse in the 1930s and had its heyday in the 1950 s to 1960 s. ${ }^{4}$ The term had different meanings both among non-Indigenous and Indigenous Australians. Whereas in the 1930s assimilation often had implications of biological absorption, in the 1950s assimilation was tied up with discourses about citizenship and Aboriginal people becoming 'full participants in the settler economy'. ${ }^{5}$ The traditional historical interpretation as summarised by Anna Haebich is that assimilation represented the promise of equal citizenship rights for Aboriginal people, but in exchange 'they were required to abandon their distinctive cultural values, lifestyles, customs, languages and beliefs and conform to the national way of life' . ${ }^{6}$ As Russell McGregor and Rani Kerin argue, there were tensions in the 1950s between policymakers who saw assimilation as the rise of individualism and gradual decline of Aboriginal traditions (a monocultural vision of assimilation), whereas anthropologists and Aboriginal supporters advocated pluralist models of assimilation where certain features of Aboriginality would be permitted and sometimes even encouraged to endure. ${ }^{7}$ In the 1960s the pluralist vision cohered into the concept of integration, whereby Aboriginal people could participate in the nation-state with equal rights while preserving their distinct cultural identities. McGregor highlights that this discursive distinction held significant meaning for Indigenous activists of the

3 Riseman 2013b.

4 See Rowse 2005; Maynard 2005.

5 Wells and Christie 2000: 117.

6 Haebich 2008: 12.

7 McGregor 2011: 101-107; Kerin 2011: 115-160. See also Haebich 2008: 110-114. 
1960s, but the difference between integration and assimilation in practice was ambiguous. $^{8}$ Indeed, the ambiguities are constitutive of the shifting meanings underpinning terms such as assimilation, integration and advancement. The nebulous nature of assimilation also led various servicemen and women to conceptualise themselves, their Aboriginality and their relationship to white Australia in different ways. One significant commonality permeates these many interpretations of assimilation: the agreement that discrimination in law and practice must end to usher in equality.

Ideas about citizenship were the bridge linking military service with assimilation because military service has traditionally been viewed as an exercise of the duties and obligations of citizenship. ${ }^{9}$ Even Aboriginal activists of the 1930s to 1940s invoked participation in the First and then Second World Wars as grounds to claim citizenship rights. Those activists considered citizenship rights to constitute political and economic equality; for policymakers in the 1950s, though, citizenship rights, military service and equality became tied up with the notion of assimilation. ${ }^{10}$ For example, the proposed 1939 New Deal for Aborigines, influential anthropologist A. P. Elkin's 1944 book Citizenship for Aborigines, and Minister for Territories Paul Hasluck's policies from 1951 explicitly promoted citizenship as the end objective for Aboriginal people and assimilation as the means. As Julie Wells and Michael Christie summarise, 'after making the transition from "primitive" to "civilised"; [individual Aboriginal people] would then be rewarded by being made citizens' ${ }^{11}$ Yet Indigenous activists of the 1960s would flip the issue of citizenship not to represent assimilation, but rather integration and equality. Veterans, including the three discussed in this article, were among the Aboriginal people who initially embraced monocultural assimilation but later re-evaluated their situations to support integration. The tensions over the meanings of assimilation, integration, equality and citizenship and how veterans negotiated these tensions will become clearer through the course of this article.

This article engages a variety of sources including newspapers, service records, magazines, Department of Repatriation files, government propaganda and oral testimonies. For all three case studies, the oral testimonies were recorded several decades after the times of service; in the case of Douglas Grant, oral recollections from those who knew him were recorded posthumously. As oral historian Alistair Thomson argues, using oral testimony from ex-service personnel is valuable to grasp how veterans remember particular conflicts and the position of military service in their life stories. Yet Thomson cautions that scholars need to consider the time that has lapsed since the events recalled because dominant narratives of historical events can shape how people reconstruct their memories. Such cautions do not make oral testimonies invalid as sources. Rather, oral

8 McGregor 2011: 107-112.

9 Janowitz 1976.

10 McGregor 2011: 50-54.

11 Wells and Christie 2000: 113. See also McGregor 2011: 34-36, 64-69, 76-97; Attwood 2003: $144-$ 148; Elkin 1944. 
histories are most valuable when contextualised with other sources of evidence. Moreover, testimonies are valuable to understand how people remember events and when viewed as markers of what individuals consider worth remembering and retelling. ${ }^{12}$ Building on Thomson's cautions, in this article oral history testimonies are presented in conjunction with other written evidence to present wider historical pictures of the events remembered, how they are remembered and why the storytellers take particular positions.

\section{Embodying the spectacle: Douglas Grant}

Douglas Grant was born in North Queensland around 1886. According to most accounts, in 1887 two Scottish emigrants rescued him from having his head smashed against a rock by Native troopers. ${ }^{13}$ The Grants raised Douglas as their adopted son in a middle-class Sydney home. Grant inherited his adopted father's Scottish accent and trained as a draughtsman and taxidermist. In 1957 Frank McNeill of the Australian Museum in Sydney said of Grant's upbringing: 'there was absolutely no differentiation because being so young and all of his formative years built him into, well, nothing more or less than a normal European' ${ }^{14}$ Grant himself later reported that other children treated him well: 'They never left me out of anything. If there was a party on, I was always taken along, too' ${ }^{15}$

Grant ran into opposition joining the Australian Imperial Force (AIF) in 1916 because of regulations prohibiting enlistment of persons 'not of substantially European origin or descent'. ${ }^{16}$ Grant's adopted father Robert pulled some strings with the New South Wales Aborigines Protection Board and the AIF agreed to keep Douglas as a special case. ${ }^{17}$ Grant's enlistment received considerable press attention; between May 1916 and January 1917 at least ten newspapers across Australia featured short articles. The first story published in The West Australian provided a brief biography before commenting:

Douglas has many accomplishments. He writes a splendid hand, draws well, recites Shakespeare with histrionic ability, plays the Scottish

12 Thomson 2006. See also Thomson 2013: 10-17.

13 This is the standard account of Grant's rescue, published in newspapers, radio and secondary sources. For an alternative account of Grant's 'rescue', see Fred G Brown, 'Douglas Grant. Queensland Aboriginal A.I.F. Digger', Townsville Daily Bulletin, 2 February 1933: 10. Grant's 'rescue' fits with other child rescue narratives of the era. See Swain and Hillel 2010.

14 Frank McNeill, in 'The Story of Douglas Grant' 1957. See also Gordon 1965: 25-29; W.A.R., 'A notable Aboriginal', The Australian Museum Magazine 10(9), 15 March 1952: 301.

15 'Pure Aboriginal reared as white man', The Mail (Adelaide), 12 February 1944: 7.

16 See Winegard 2012: 87; Pratt 2007: 221-222.

17 'Aboriginal Soldier. Story of Douglas Grant', Sydney Morning Herald, 2 September 1916: 20. Article reprinted in Morning Bulletin (Rockhampton), 9 September 1916: 10; The Capricornian (Rockhampton), 16 September 1916: 40; The Northern Miner (Charters Towers), 21 September 1916: 2; Worker (Brisbane), 4 January 1917: 17. See also Huggonson 1993: 215-216. 
bagpipes, and can earn a very good living any time by following his profession - that of a draughtsman. This brief history demonstrates what may be done with an aboriginal when taken early and trained. ${ }^{18}$

This was the first of many articles which depicted Grant as a spectacle during the war - a 'cultured' Aboriginal soldier living like a white man. This was an era when assimilation discourse was not common in Australia. Even so, such ideas about 'training' a young Aboriginal child aligned with child rescue discourse and constituted a form of proto-assimilationism. ${ }^{19}$

Grant served on the Western Front before being captured as a prisoner of war in May 1917. The Germans recognised Grant as intelligent and therefore appointed him to be in charge of Red Cross parcels for Indian civil prisoners at the POW camp. ${ }^{20}$ In one letter to the Australian Red Cross he wrote:

Could I also get a copy each in book form the poems of Adam Lindsay Gordon, Henry Lawson, and Robert Louis Stevenson, or some books of Australian life .... Perhaps Madam you are aware that I am a native of Australia, adopted in infancy and educated by my foster parents whose honored name I bear, imbued me with the feelings and spirit of love of Home, Honour, and Patriotism. ${ }^{21}$

Grant's language suggests pride in being an 'assimilated' Aboriginal person (though he does not use that term). His invocation of patriotism suggests that military service represented a natural progression of his upbringing in white Australia. Interestingly, though, because Grant did not adequately conform to the 'science' of the time, the Germans found it difficult to reconcile Grant's race as an Aboriginal man with his European upbringing. ${ }^{22}$

After the war Grant had difficulty finding continuing employment. From 1925-27 he even moved to Melbourne then to Barmah, Victoria to pick fruit. He subsequently returned to New South Wales and worked at a small arms factory in Lithgow until he was retrenched in 1929. Throughout this period and especially after his retrenchment, he frequently sought employment related to his draughtsman or taxidermy training at a museum, but because he was black he could only secure casual labouring jobs. Letters in his Repatriation file indicate that he was relying almost exclusively on a war pension for income. Eventually Grant became a clerk, messenger and errand boy while residing at the Callan Park Mental Hospital. ${ }^{23}$

18 'An Aboriginal soldier', The West Australian, 23 May 1916: 5. Article reprinted in Gippsland Times, 17 July 1916: 4.

19 Swain and Hillel 2010.

20 Mitchell Library, ML MSS 2766.

21 Douglas Grant, to Miss Chomley, Australian Red Cross, 5 May 1918, in National Library of Australia (hereafter NLA) MS 9058.

22 See Dr Leonard Adam, in 'The Story of Douglas Grant' 1957; Gordon 1965: 27.

23 'The Story of Douglas Grant' 1957; NAA Sydney, series C138, item R70396 DOUGLAS GRANT; 'Retrenchment. Air Force. Randwick station closing down', Sydney Morning Herald, 5 July 1929: 13; Gordon 1965: 28-29; NAA Canberra, series B2455, item GRANT D.; 'Relics of Aborigines. 
Grant occasionally reappeared in newspapers throughout the 1920s and 1930s. Frequently he was listed with writer and inventor David Unaipon and missionary James Noble as evidence of "what can be done to raise the status of the aboriginal and equip him for the tasks of civilised life' ${ }^{24}$ Such discourse presaged assimilationist language that emerged in the 1939 proposals for a New Deal for Aborigines. Even David Unaipon referenced himself and Grant as examples of why assimilation could successfully lift the status of Aboriginal people. Unaipon remarked: 'Here was a baby [Grant] brought straight from the wilds of Queensland and absolutely primitive antecedents. Yet see what he has done!' ${ }^{25}$ Grant's position within white society included serving as the Secretary of the Lithgow Returned Soldiers' and Sailors' Imperial League of Australia (RSSILA) for three years; he also conducted the local radio returned soldiers' session. ${ }^{26}$ Roy Kinghorne of the Australian Museum later remarked, 'We all regarded Douglas as one of ourselves, and when he put out his hand to shake hands, it wasn't a black hand somehow or other. It just seems as if he was just a white hand; he spoke like ourselves and was one of ourselves in every way' ${ }^{27}$ Unaipon and Kinghorne's depictions of Grant embodied the later notion of assimilation representing a means to uplift Aboriginal people, for which they should be grateful. ${ }^{28}$ By the 1950s, when assimilation was the mainstream policy for Indigenous people across Australia, Grant's story was being used as propaganda to promote assimilation through media such as the $A B C$ radio broadcast. Such media did not portray military service as the only facilitator of Douglas Grant's assimilation; rather, military service represented one component of a long assimilation process that began with his childhood in a white family.

Whereas the white press portrayed Douglas Grant as a positive example of assimilation, he confronted discrimination and gradually began to criticise white society for limiting Aboriginal people's ability to assimilate. While Secretary of the Lithgow RSSILA, Grant was on record opposing racial discrimination in public facilities and sport, writing 'The colour line was never drawn in the

Collection presented to the nation', Sydney Morning Herald, 22 January 1931: 8.

24 Percy S Allen, 'Bushrangers and blackfellows: orders to Phillip', Sydney Morning Herald, 24 January 1938, 19. Other references to Grant, Noble and Unaipon as successful examples of assimilation include 'Diary of a man about town. Aboriginals of note', The Mail (Adelaide), 31 October 1925: 2; 'The Sydney Mail', Sydney Morning Herald, 11 July 1917: 10; 'Australia's natives. Their history and their future', Cairns Post, 7 October 1930: 2; 'A tragic story. Slaughter of blacks', Sydney Morning Herald, 18 April 1931: 13; 'A tragic story. Slaughter of blacks', The Northern Miner (Charters Towers), 13 May 1931: 2; 'Holy orders. The Rev. James Noble', Townsville Daily Bulletin, 10 January 1934: 3; Goorine, 'The Aborigines question (To the Editor)', Townsville Daily Bulletin, 12 May 1937: 15; E.R.B.G., 'The Australian Aborigines', Cairns Post, 26 January 1940: 11; 'Care of Aborigines', The West Australian, 30 January 1940: 10.

25 'An Aboriginal intellectual. David Unaipon', The Register (Adelaide), 3 October 1925: 9.

26 'Colour Line again', Mercury (Hobart), 24 June 1929: 6; 'Retrenchment. Air Force. Randwick station closing down', Sydney Morning Herald, 5 July 1929: 13; 'Sidelights. Scotch Aboriginal', Brisbane Courier, 10 August 1929: 24; 'A sermon - in black and white', Western Mail (Perth), 10 October 1929: 2; E.R.B.G., 'The Australian Aborigines', Cairns Post, 26 January 1940: 11; W.A.R., 'A notable Aboriginal', The Australian Museum Magazine 10(9), 15 March 1952: 301.

27 Roy Kinghorne, in 'The Story of Douglas Grant' 1957.

28 Haebich 2008. 
trenches' ${ }^{\prime 29}$ The discrimination Grant witnessed persisted even into the post-war assimilation era and constituted one of the shortcomings of assimilation policies. Whichever version of assimilation one advocated - whether the pluralist or monocultural model - there was a hope that non-Indigenous Australians would accept and welcome assimilated Aboriginal people into their communities. This was not the case, and despite the efforts of assimilationists to oppose racial discrimination, prejudice persisted. ${ }^{30}$ Grant clearly was not immune to such treatment; indeed, his experience foreshadowed other Aboriginal people in the post-war period, and like many others Grant grew disenchanted.

In the early 1930s, Grant looked to empower Aboriginal people to embrace assimilation. He applied as an architect to design cottages for an Aboriginal settlement at La Perouse in Sydney. Grant unsuccessfully argued that 'his services as architect should be utilised because, as an aborigine, he knows and understands the needs of his race'. ${ }^{31}$ By 1933 Grant was actively advocating (unsuccessfully) for Aboriginal self-determination on remote reserves, referencing Native American reservations. Grant argued that:

given an opportunity to develop free from white influence the high communal spirit of pre-settlement days, could be used usefully to occupy outposts in the continent where at present the European could not go. Let him develop naturally, not merely stay around missions, and let him become an asset instead of a drag. ${ }^{32}$

Such ideas were consistent with assimilationist discourse, as many advocates considered segregation of remote Aboriginal people necessary because they were either not capable or not ready to assimilate. By 1944 Grant was calling for full citizenship rights for Aboriginal Australians. He remarked, 'Australia is the aboriginal's by birth - the Australian's by adoption ... Surely after 150 years the Government can see its way clear to uplift and emancipate the Australian aboriginal'. ${ }^{33}$ Such arguments were not dissimilar to those advanced by Aboriginal activists of the inter-war era such as Jack Patten, Fred Maynard or William Ferguson. ${ }^{34}$ There are no indications that Grant had any connections with these or other Aboriginal activists. In fact, Frank McNeill asserts that Grant 'never associated himself with his own race ... He considered them something very very different and that's why the experiment of bringing up Doug as he was brought up and educating him as he was educated was rather a tragic

29 'Colour Line again', Mercury (Hobart), 24 June 1929: 6.

30 McGregor 2011: 88-93; Haebich 2008: 214-234.

31 'Full-blooded Aborigine architect seeks to benefit his people', The Register News-Pictorial (Adelaide), 3 September 1930: 7. See also 'Aborigine an architect. Fought with A.I.F.', Advocate (Burnie), 2 September 1930: 6.

32 The Northern Miner(Charters Towers), 25 February 1933: 4; 'The Aborigines. Interesting plea. Give them an opportunity', Townsville Daily Bulletin, 25 February 1933: 10.

33 'Pure Aboriginal reared as white man', The Mail (Adelaide), 12 February 1944: 7.

34 See McGregor 2011: 37-54; Maynard 2007; Attwood 2003: 194-197. 
experiment'. ${ }^{35}$ Even though Grant did not associate with Aboriginal people in the 1930s to 1940s, his proposals suggest that he considered his daily encounters with discrimination to mirror other urban Aboriginal experiences.

Grant's life spiralled downhill through the 1930s after the deaths of his foster brother and parents left him with no support network. Observers indicate that he drank heavily as feelings of rejection took their toll. Grant's Repatriation file indicates that he was an inmate at the Callan Park Mental Hospital from 1931 until 1939 because of a 'mental disorder [which] appears due to alcoholism'. One 1939 letter from the medical superintendent at the hospital described Grant as 'an incorrigible alcoholic with mild alcoholic dementia and will never improve'. Throughout the 1940s medical reports frequently referred to him as 'depressed' or 'melancholic'. ${ }^{36}$ Roy Kinghorne observed:

He used to enjoy himself at the reunions after the war, but he became a sadder, progressively more dejected figure as each April the twenty-fifth went by. One day, in the late 'forties, I saw him sitting under a tree as the fellows from my old unit were marching into the Domain ... ' I'm not wanted any more,' Grant told me. 'I don't want to join in. I don't belong. I've lived long enough'. ${ }^{37}$

In 1949 Grant was classified as totally and permanently incapacitated due to heart disease and began to collect a Special Rate pension. He died in 1951 of a brain haemorrhage at The War Veterans' Home on Bare Island near La Perouse. ${ }^{38}$

Media reports after Grant's death continued to portray military service as one of several life events which facilitated his assimilation. At the time of Grant's actual service, though, there was no assimilationist agenda pushing for Aboriginal military service. Reports during the war merely gave Grant a public profile as an Aboriginal soldier. In the 1930s to 1950s the media retrospectively determined military service to be one of several catalysts - child removal being the other main one - within Grant's constructed assimilation narrative. Such a narrative suited the agenda of 1950s monocultural assimilationists such as Hasluck, who envisioned Aboriginal Australians living like white Australians while gradually losing their own customs. That Grant himself questioned non-Indigenous Australians' willingness to accept 'assimilated' Aboriginal people was overlooked in public discourse. This did not constitute Grant's rejection of assimilation per se, but rather revealed his frustration with a process that required the embrace of not only Aboriginal people, but also the white community. The media's final word on Grant's life came in the 1957 ABC report: 'He was an indication of the fact that the Australian Aboriginal has plenty of latent intelligence - well it's an intelligence that can be brought out under kindly and scientific treatment ${ }^{\prime}{ }^{39}$

35 Frank McNeill, in 'The Story of Douglas Grant' 1957.

36 NAA Sydney, series C138, item R70396 DOUGLAS GRANT.

37 Roy Kinghorne, in Gordon 1965: 29. See also Roy Kinghorne, in 'The Story of Douglas Grant' 1957; Lucy 1988: 149.

38 NAA Sydney, series C138, item R70396 DOUGLAS GRANT.

39 Alex Chisholm, in 'The Story of Douglas Grant' 1957. 


\section{Soldier for the Queen? Reg Saunders}

The 1930s marked the rise of assimilationism as well as the build-up to the Second World War. During this period there were calls from various organisations for the armed forces to employ Aboriginal men of mixed descent in segregated units to hasten the assimilation process. ${ }^{40}$ Notwithstanding such proposals, in 1940 the Commonwealth explicitly prohibited the enlistment of all persons of nonEuropean origin or descent. Even so, at least 3,000 Aboriginal and 850 Torres Strait Islander men and women served in the Second World War, primarily because the Pacific War necessitated all available manpower and womanpower. ${ }^{41}$ Among those servicemen was Reg Saunders, whose story exemplifies how assimilationists propagandised Aboriginal military service after the war.

Reg Saunders was born in 1920 into a prominent Gunditjmara family from Framlingham and Lake Condah in Victoria. Reg's uncle and father served in the First World War and his younger brother Harry would die in action in New Guinea during the Second World War. Saunders' first wife Dorothy served in the Women's Auxiliary Australian Air Force, so military service was quite prominent in the Saunders family. Reg left school after grade eight and worked in a sawmill and then in a timber-cutting business with his father and brother. ${ }^{42}$ Reg joined the Army in April 1940; framing his motivations, he remarks, 'No I never fought for anybody but Australia. I always was loyal to my country .... Australia is my country and I'd merely followed in the footsteps of hundreds of other Aboriginals in World War I' ${ }^{43}$

Reg's strong personality, friendly nature and leadership abilities led to his promotion to Sergeant before he left Australia. In November 1940 Saunders arrived in North Africa, fighting with the 2/7th Battalion against Italian forces. He also served in the doomed defence of Greece and Crete in early 1941. Saunders and others in his unit hid among Cretan villagers for 11 months before escaping to North Africa. By August 1942, Saunders was back in Australia and was then deployed to New Guinea in April 1943. Saunders testifies that he did not experience much racism in the Army. He remarks:

I didn't strike any racism in the Army though. I had a bit of a reputation as a fighter - I don't know where I got it from - and well, there were a lot of good Aboriginal fighters in those days... So I didn't get very much cheek from anybody. I didn't get any, as a matter of fact. But I never

40 See several proposals in: NAA Melbourne, series B1535, item 929/19/912; NAA Canberra, series A659, item 1939/1/12995; NAA Melbourne, series B1535, item 849/3/1644; NAA Melbourne, series MP508/1, item 82/712/670; NAA Melbourne, series MP508/1, item 275/750/1310; NAA Melbourne, series MP508/1, item 240/701/217; NAA Canberra, series A659, item 1942/1/3043.

41 See Hall 1997.

42 Gordon 1965: 35-43.

43 Australian War Memorial (hereafter AWM) S00520. 
asked for it, I just used my rank the way it should have been used, I didn't abuse it, and I was more friendly with fellows and didn't rely on military discipline to get my way. ${ }^{44}$

Saunders' success on the battlefield caught the attention of superiors and he was invited into Officer Training School. On 25 November 1944 Reg Saunders was the first Aboriginal serviceman to graduate as a commissioned officer in the Second AIF. ${ }^{45}$ One of the officers on the selection committee remembers, 'I said after he left the room, "Here is a bloke able to lead troops. We couldn't care whether he is black, white or brindle. Let's give him a go"' ${ }^{46}$ The decision to give an Aboriginal man a commissioned command required the approval of General Thomas Blamey, who wrote, 'If the Commanding Officer of the 2/7th. battalion is prepared to accept Sergeant Saunders as an officer, I'm certainly prepared to do the same' ${ }^{47}$ Saunders was modest about breaking this colour barrier, stating 'So I wasn't aware that there was anything extraordinary about me, but I thought I was a pretty good soldier' ${ }^{48}$ At the end of the war Saunders left the Army.

In 1950 Reg re-enlisted into K Force in the Korean War. Financial motives were front and centre; Reg recalls, 'Where else can I get $£ 21$ a week, all hospital expenses, three meals a day and an allowance for my wife?' ${ }^{\prime 9}$ Reg served as commander of 3RAR's C company battalion, even fighting at the Battle of Kapyong. He returned to Australia in early 1952 and trained soldiers of 2RAR for service in Korea. ${ }^{50}$ Later he was responsible for training national servicemen. Reg resigned from the Army in October 1954, citing the low quality of national servicemen as the reason. He commented, 'There were too many officers' parties at weekend camps. The men at times were allowed to do much as they pleased' ${ }^{51}$

At various times during and especially after the Second World War, Reg Saunders had a significant media profile. Like Douglas Grant, much of the reporting focused on Saunders as a 'model' Aboriginal person who had successfully assimilated in Australian society. Wheeling out 'model' Aboriginal people, particularly 'celebrities', was dual-purpose propaganda. It both encouraged white Australians to accept assimilated Aboriginal people as 'like them', while concurrently suggesting to Aboriginal people that they, too, could make it in mainstream Australia. ${ }^{52}$ Reports in 1944-45 frequently mentioned Saunders as

44 Reg Saunders, in Hall 1995: 77. For Saunders' service records see NAA Canberra, series B2458, item 337678: SAUNDERS, Reginald Walter. A narrative of Saunders' Second World War service is available from Gordon 1965: 49-132; Ramsland and Mooney 2006: 182-191; Grimshaw 1992: 88-93; Chris Saunders, in Jackomos and Fowell 1993: 20-22.

45 Traditionally Saunders is considered the first Aboriginal officer in the armed forces, but researchers recently identified a Tasmanian Aboriginal officer from the First World War.

46 In Ramsland and Mooney 2006: 187.

47 General Thomas Blamey, in Gordon 1965: 16.

48 Saunders, in Hall 1995: 80.

49 Saunders, in Gordon 1965: 142.

50 For Saunders' Korean War service see Gordon 1965: 144-158; Ramsland and Mooney 2006: 194195; Grimshaw 1992: 93-97.

51 'Aboriginal tells Army why he quit', Melbourne Herald, 12 March 1956, in NAA Canberra, series B2458, item 337678. See also Gordon 1965: 160-162.

52 Haebich 2008: 152; McGregor 2011: 74; Wells and Christie 2000: 113-117. 
the first Aboriginal officer in the Australian Army. Coverage after the war ranged from a photo of Saunders' daughter on Santa Claus' lap, to Saunders starring in a local pantomime revue, to Saunders' wife and daughters greeting him at Spencer Street Station when he returned from Korea. ${ }^{53}$ Such imagery aligned with government efforts to 'sell' assimilation to the white Australian public. ${ }^{54}$ In 1953 there was a media storm over whether to send Saunders to Queen Elizabeth II's coronation as part of Australia's military contingent. Ultimately Saunders was not included, but in 1955 new proposals advocated that Saunders light the cauldron at the 1956 Melbourne Olympics; this proposal, too, was unsuccessful. ${ }^{55}$ One article from the Melbourne Herald encompasses the media's attitude towards Reg Saunders: 'It has been frequently demonstrated that an Aboriginal of normal intelligence ... can lift himself to the standard of his white brethren. The case of Lieut. Saunders emphasises this truth' ${ }^{56}$ As Haebich summarises, stories such as these sent the message 'that they had been able to succeed in spite of this impediment [being Aboriginal]' ${ }^{57}$

Most media coverage of Saunders the war hero and model of assimilation did not mention the difficulties he confronted as a civilian Aboriginal man. Between the Second World War and Korean War, Saunders worked in low-wage jobs such as a tram conductor, foundry worker and tally clerk. After the Korean War he again returned to low-wage positions. ${ }^{58}$ His daughter Glenda recalls,

Dad had done extremely well ... yet at the end of it, there was nothing for him. Some of the guys have said to me, 'I can't believe that he wasn't offered the types of jobs other people were offered'. I can only think the reason was the colour of his skin..$^{59}$

Saunders had amicable relations with his colleagues but had to confront racial discrimination from the public. He recalled several incidents when tram passengers racially abused him, though he always stood his ground and often kicked those passengers off. He also confronted racial vilification on the streets of Melbourne or Sydney or on the football field. He was often refused alcohol in pubs. ${ }^{60}$

One topic where media coverage revealed the gap between white and Aboriginal perceptions of assimilation's impact involved the Saunders family's living situation. Assimilation policies in several states including Victoria encouraged

53 'Hero's kiddies meet Santa', The Argus (Melbourne), 21 December 1950: 4; 'Revue company for Portland', Portland Guardian, 13 January 1947: 2; 'Home from Korea', Portland Guardian, 10 March 1952: 2; “"Daddy's safe home again!” - with Geisha Dolls, too', The Argus (Melbourne), 18 January 1952: 3; 'Spencer St stopped work to cheer him', The Argus (Melbourne), 18 January 1952: 3.

54 Haebich 2008: 118-121, 137-154.

55 Gordon 1965: 164.

56 Melbourne Herald, in Pottinger 2000: 34.

57 Haebich 2008: 152. See also McGregor 2011: 74; Wells and Christie 2000: 113-117.

58 Gordon 1965: 165-168.

59 Glenda Hume, in Pottinger 2000: 34.

60 Gordon 1965: 138-139. 
Aboriginal people to move into houses in townships or cities. ${ }^{61}$ Yet Reg Saunders and his family confronted discrimination when applying for rental housing, being relegated to cramped tenements in industrial suburbs like other Aboriginal residents. This situation came to the media's attention when Saunders' wife wrote a letter to the Sun News-Pictorial detailing the poor living conditions where she and her children dwelled. The Sun reported:

In this room of a condemned house - the only home that a war hero and his family could find in years of searching - the youngest baby has been bitten by a rat, and there are great gaps in the broken, sunken flooring. A patch of wet mud lies at the doorway, where the floor has been worn right away. ${ }^{62}$

The media attention had an impact; a man who knew Reg from the Army contacted Dorothy Saunders and offered her a furnished, affordable house in a leafy suburb. ${ }^{63}$ While this was a good outcome for the Saunders family, it demonstrates one way in which white Australians overlooked the realities of discrimination confronting Aboriginal Australians. None of the coverage explained that racial discrimination was what prevented the family from renting a decent home. Rather, it merely presented the Saunders' situation as unique and with a happy ending that warranted no further investigation.

The housing situation is one example of discrimination facing all Aboriginal people during the assimilation era. Even so, throughout the 1940s to 1950s Saunders embraced assimilation for its promise of equality. He tried to live and work with white Australians and no longer resided in Aboriginal communities. When his marriage with Dorothy fell apart in 1953, he subsequently partnered with and eventually married a white woman. A line in Saunders' Aborigines' Welfare Board file commented in 1956 that 'Reg's present partner I am told is a white woman possibly a nurse so he is at least being assimilated' ${ }^{64}$ Saunders commented in his 1962 biography: 'Ultimately, I suppose, there'll be assimilation, but it will take hundreds of years'. Reg further used his son Chris as an example:

'He could be totally assimilated. He's a good-looking boy, not too dark, very popular, better than average at sport. And he's very bright at school. You never know.... Chris might one day get to university. And he'll certainly marry a white girl. ${ }^{65}$

That even Saunders argued an assimilationist approach to Aboriginal affairs demonstrates the strength of the ideology within early 1960s Australia. As Kerin asserts, many historians and Aboriginal people are hesitant to admit 'that many Aborigines supported assimilation' because of the negative connotations

61 See Haebich 2005; Manning 2005.

62 In Gordon 1965: 146; Ramsland and Mooney 2006: 195.

63 'Home offered to officer's family', The Advertiser (Adelaide), 20 November 1950: 3; see also 'Hero's wife to leave the slums', The Daily News (Perth), 21 November 1950: 4-5.

64 Typed note in NAA Melbourne, series B337, item 664.

65 Gordon 1965: 172. 
associated with the term today. ${ }^{66}$ Assimilationists asserted that the Army was the catalyst for Saunders' 'successful' assimilation and therefore was a possible path for other Aboriginal people. In 1951 Mufti, the Victorian RSL newsletter, proposed an all-Aboriginal battalion. The magazine argued, 'Captain Saunders has provided proof in abundance, if proof were ever needed, that with training the aborigines can become as good if not better in many respects as the white'.$^{67}$ This proposal did not come to fruition, and Aboriginal service personnel in the 1950 s to 1960 s continued to serve integrated in normal units.

When the 1960s ushered in new opportunities for Aboriginal leadership, Saunders was already involved in the fight for Aboriginal equality and continued to adhere to assimilationist discourse. He recalls, 'I felt a sense of leadership of Aboriginal people and a desire to do something about the Aboriginal situation, yes, yes ... I would have liked to have done more than I did do' ${ }^{68}$ As early as 1946, Saunders was opposing the bar against Aboriginal servicemen joining the British and Commonwealth Occupation Forces (BCOF) in Japan. He wrote, 'Now that the danger [war] is past I feel my race is entitled to equal opportunities with other Australians. We don't want privileges, but opportunities for advancement and fair treatment' ${ }^{\prime}{ }^{9}$ Saunders was invited to be a guest speaker at Martin Place in Sydney for the 1961 National Aborigines Day - part of National Aborigines' Day Observance Committee (NADOC) Week. ${ }^{70}$ Saunders recalls that a state cabinet minister who shared the platform with him still advocated that Aboriginal people should be relegated to reserves until they 'earned' their place in Australian society, reflecting assimilationist discourses about reserves serving as staging areas until 'tribal' Aboriginal people were 'ready' to assimilate. He confronted the politician and said, 'One day you're going to regret that' ${ }^{71}$ From 1969 Saunders began working as an advisor in the Commonwealth Ministry for Aboriginal Affairs, where he was popular with Aboriginal communities he visited. By this time, just as assimilation ideology was on the way out, much of Saunders' work centred on developing initiatives to support Aboriginal selfmanagement, such as encouraging the Walgett Aboriginal community to set up a credit union in 1972. After a heart attack in 1980, he worked in a casual capacity until he passed away from heart failure in March 1990. ${ }^{72}$

Saunders' story is similar to Douglas Grant's as someone that white Australians could promote as a 'safe' model of assimilation. Saunders like Grant embraced the assimilation agenda because he saw it as a legitimate path to equality for

66 Kerin 2011: 152.

67 'Aboriginal unit proposed', Cairns Post, 5 November 1951: 1; 'Aboriginal battalion', Morning Bulletin (Rockhampton), 5 November 1951: 4; 'Aboriginal battalion suggested', The Advertiser (Adelaide), 5 November 1951: 2.

68 Saunders, in Hall 1995: 87.

69 Saunders, in Gordon 1965: 136-137; Ramsland and Mooney 2006: 193.

70 Mrs Joyce Rogalsky, Secretary, NSW State Committee for NADOC, to Central Army Records Office (hereafter CARO), 12 December 1960, in NAA Canberra, series B2458, item 337678.

71 Saunders, in Gordon 1965: 142.

72 Ramsland and Mooney 2006: 200-201; Moodie 1989: 17; Pottinger 2000: 36; Glenda Humes, in Jackomos and Fowell 1993: 19. 
Indigenous Australians. Yet while the media portrayed Saunders as a successful product of assimilation through Army service, he gradually grew frustrated with the unfulfilled promise of equality. As ideas questioning the efficacy of assimilation arose in the 1960s, only then did Saunders re-evaluate his own position and shift support for a more pluralist approach. Yet his support for assimilation as the route to equality ran deep. Summarising Saunders' attitude, in 1962 when asked what he would like to do to improve the lot of Aboriginal Australians, Saunders responded: 'I'd try to ginger up some pride of race among the aboriginals themselves. And I'd work to have discrimination based on colour made a punishable offence in Australia'. ${ }^{73}$

\section{Stolen Veteran: Phillip Prosser}

In the 1950s to 1960s the links between the armed forces, citizenship and assimilation became more explicit and were no longer isolated to individuals, although there were still 'poster children' such as Reg Saunders and, as outlined below, Phillip Prosser. There were recurring references to Aboriginal people in the armed forces in the New South Wales Aborigines Welfare Board magazine Dawn. The publication was meant to keep Aboriginal residents of New South Wales informed about the activities of the Aborigines Welfare Board on reserves, missions and in homes across the state while providing other local, national and international news. The Korean War, for instance, featured quite prominently in the 1952-54 issues of Dawn. At least one article propagandised Aboriginal servicemen preparing for Korea: 'The aboriginal people gained further credit for themselves last week when one of their number parachuted from a plane near Newcastle. He was L/Corporal Stan Houston, full-blooded aborigine of Rockhampton, and he had just graduated as a paratrooper at the Williamstown RAAF station'. ${ }^{74}$ The cover of the November 1956 issue of Dawn featured an Aboriginal man demonstrating boomerang throwing to a Korean woman. Sporadic articles through the late 1950s to early 1960s continued to feature stories about military service. Some articles specifically referenced Indigenous service, while others were simply generic stories about the armed forces. Stories included references to Reg Saunders, images of servicemen heading to Malaya and references to Anzac Day services at Gallipoli. ${ }^{75}$ All of these articles frequently promoted the armed forces as a site of opportunity for Aboriginal men and women to perform obligations associated with citizenship.

Taken collectively these articles almost read like a series of recruitment advertisements. One article that most prominently fit that profile was from May 1964 entitled 'Aborigines Discover Advantages in Army Life'. The opening sentence summarises the article's message: 'Serving side by side with many thousands of other Australians in the Regular Army today are a number of young

73 Saunders, in Gordon 1965: 171.

74 'Aboriginal paratrooper: Australia's first', Dawn, April 1952: 13.

75 See Dawn, July 1956, November 1956, August 1957, December 1958, July 1961, February 1962 , April 1963, April 1964. 
Aborigines who have discovered advantages in this career' ${ }^{\prime 6}$ The article details the different aspects of training, corps, life in the Army, skills development, education opportunities and wages. The article includes images of Aboriginal servicemen happily working with and learning from white servicemen. It concludes with a contact address for Aboriginal people interested in signing up. ${ }^{77}$ Formal recruitment advertisements appeared in later issues of Dawn, particularly during the Vietnam War. An advertisement in August 1967 even promoted careers in the women's services. ${ }^{78}$ The presence of these advertisements in Dawn - a magazine designed to promote assimilation - reveals that the New South Wales Aborigines Welfare Board clearly saw the armed forces as a vehicle to promote assimilation. Stories would continue to profile Aboriginal service in Vietnam in issues from 1965-70.79

Among the Aboriginal soldiers in Vietnam who fit the assimilationist discourse was Phillip Prosser, born in Busselton, Western Australia in June 1939. Before he was five, the police removed him from his grandmother's care. The Native Welfare Department sent Prosser to be raised at Roelands mission. He had occasional visits from his father and grandmother, but Prosser grew up in the institution with little connection to his kin or culture. It was a difficult, disciplined, regimented childhood; like other institutions at the time, the education was geared towards training boys for manual farm labour and women as domestic servants. Prosser was fortunate, though, that he won a scholarship to study at the Perth Modern School. Even with more education than most Aboriginal children, Prosser recognised that the discrimination he confronted as an Aboriginal man limited his options. He testifies:
But I also knew, growing up, because of things that had happened to me as a young Aboriginal kid, that if I was to remain here in WA I would not make it in many respects. Because of the way, because of the situation in terms of, issues that affected Aboriginal people in those days. Like, half- past-six you were out of town, you know. To be seen and not heard. And all the obstacles that were facing me as a young person growing up. And I saw the Army as a way out for me. ${ }^{80}$

The notion of the Army as an escape was not uncommon for survivors of institutional out-of-home care, both Aboriginal and non-Indigenous. ${ }^{81}$ Like Grant and Saunders before him, Prosser would find the Army to be an empowering career while concurrently the government and media used him to promote Aboriginal assimilation.

Prosser adapted well to the regimentation of the Army because of his institutional upbringing. He recalls, 'I was able to accept a lot of discipline because the

\footnotetext{
76 'Aborigines discover advantages in Army life', Dawn, May 1964: 9.

77 'Aborigines discover advantages in Army life', Dawn, May 1964, 9-11.

78 Dawn, August 1967: 12.

79 For a history of Aboriginal service in Vietnam, see Riseman 2012.

80 NLA TRC 5000/183.

81 Riseman 2011; Australia 2004: 161; Murray et al 2008: 132-133.
} 
discipline that was meted out to me in the Army was nothing compared to what I had to have when I was a young kid growing up in the home' ${ }^{82}$ Prosser signed up to the cadets in 1957 and enlisted in the regular Army in 1963; he served in Malaya and did a tour of duty in Vietnam from May 1966-67. He remained in the Army until 1975, leaving for family reasons. Throughout his military career, he received praise from officers for his leadership abilities and for his practical operations skills. ${ }^{83}$ Though treated as an equal within the Army, Prosser still experienced discrimination in civilian Australia. He recalls:

And we went down, went into town to have a few drinks. And we walked in, sat down in the lounge area of the Hotel Manly, as it was known in those days. And the steward came up to take orders. Of course he went around the table, and when he came to me, he said- he turned to me he, the guy said, 'I'm sorry; I can't serve this gentleman because he's Aboriginal'. And of course they became pretty upset, the guys. They said, 'But he's in the Army. You've got to serve him'. He said, 'I'm sorry but we can' $t^{\prime}$. So he refused to serve me. ${ }^{84}$

When confronting such discrimination, memories of his white army buddies standing up for him are also prevalent. Prosser remembers one mate saying,

'Those bastards can't touch you any more'. He says, 'You're a member of Her Majesty's Forces'. And I thought about it later, it made me feel good. That was my first introduction into equality from white society, as I saw it at the time, and that was the start of my Army career. ${ }^{85}$

During the time of Prosser's upbringing and military service, a series of Commonwealth Department of Territories information pamphlets beginning in 1957 with Our Aborigines promoted the 'successful' assimilation of Aboriginal people to white Australians. These pamphlets disseminated information rife with stereotypes of primitivism about 'traditional' Aboriginal societies, as well as information about the 'assimilated' Aboriginal people who were functioning as active citizens in mainstream Australian society. ${ }^{86}$ Among these pamphlets was one in 1961 entitled One People; the final section of the booklet was entitled 'Some Successful Aborigines', profiling stories of 'assimilated' Aboriginal people 'who - sometimes largely by their own efforts, sometimes with the generous help of other Australians - have established for themselves an honoured place in our community' ${ }^{87}$ The profiled Aboriginal people included sportsmen, entertainers, pastors and Aboriginal servicemen - Reg Saunders, Second World War veteran Timothy Hughes and Phillip Prosser. Of Prosser, the pamphlet stated:

82 NLA TRC 5000/183.

83 Phillip Prosser service records, service number 54832, available from CARO.

84 Phil Prosser, in The Forgotten 2003.

85 NLA TRC 5000/183.

86 For analysis of these pamphlets, see Haebich 2008: 137-158; McGregor 2007; Mickler 1998: 94101.

87 One People, prepared by the Department for Territories, for use by the National Aborigines' Day Observance Committee on the celebration of National Aborigines' Day, 14 July 1961: 27. 
The original Australians are still worthily represented in their country's armed forces - by such men as Driver Phillip Prosser. Driver Prosser got his taste for soldiering in the Cadet Corps of the Perth High School. Subsequently he left his apprenticeship as a carpenter and joiner to enlist in the army. In 1957, after completing a Driving and Maintenance Course at Sydney's North Head, he became the Commanding Officer's driver. ${ }^{88}$

This description of Prosser, both as an individual and in conjunction with the popular image of Saunders, represented a government attempt to link the armed forces to the project of assimilation. The brochure summarised 'in war, aborigines, or men of aboriginal descent, have won the respect and affection of their fellows' ${ }^{89}$ Such propaganda aligned with the discourses about uplifting the primitive before earning citizenship rights, and it had some impact on nonIndigenous readers. Noongar Elder Hazel Brown recalls encountering proponents of Aboriginal service in Vietnam in Gnowangerup, Western Australia. One argued: "'Look Hazel you know the trouble with your people is, your people are lazy. Most of them [Aboriginal people] won't work." He said, "Army'll be good experience"'. ${ }^{90}$ Hazel Brown rejected such assertions of idleness, but her testimony reveals the strength of the discourse about 'lazy' Aboriginal people and the Army representing a 'positive' site of assimilation.

Many of those Indigenous men and women who served in the 1960s-70s interpreted assimilation differently from the monocultural approach. Namely, by this period many advocates of assimilation did not believe that Aboriginal people should have to sever their cultural ties to become equal citizens. As Kerin argues, there were some who considered assimilation an opportunity to bring Aboriginal culture into mainstream Australian life. She describes such interpretations of assimilation as 'an assimilation which celebrated rather than suppressed Aboriginality' ${ }^{91}$ Phil Prosser's testimony aligns with this pluralist vision of assimilation; he describes how he did learn leadership skills in the Army, but not at the cost of his own culture. He remarks: 'To me it was a way of getting away from this welfare mentality that you could see what was happening in the terms of the old Native welfare days. The way they treated Aboriginal people or Aboriginal people were treated. And so to me it was a way out'. ${ }^{2}$ Prosser used the opportunities provided in the Army to set himself up for later in life: 'Well it gave me the chance that I'd been looking for. A polite way to do things and to prepare me for later stages of my life. It furthered my, I was able to further my education'.$^{93}$

Prosser's life since exiting the Army in 1975 has not been without problems, particularly the post-traumatic stress disorder he suffers as a consequence of his Vietnam experience. Yet he has become a significant leader in the

88 One People, 30.

89 One People. Emphasis added.

90 Scott and Brown 2005: 153.

91 Kerin 2011: 116.

92 Phil Prosser, in The Forgotten 2003.

93 NLA TRC 5000/183. 
Western Australian Aboriginal community, advocating for Indigenous selfempowerment. Since 1988 he has been involved in a program administered by the Western Australia Ministry of Justice called the Aboriginal Visitors Scheme. Initiated as a result of the Royal Commission into Aboriginal Deaths in Custody, the scheme entails sending visitors to local prisons and police lock-ups to provide counselling to Western Australian Aboriginal prisoners. Prosser states:

That service includes giving them support whilst they're incarcerated, in issues such as, crisis management, suicide intervention, and general counselling in issues that which may affect them whilst they are in prison, or in the lock-ups. Things like family, family welfare, general welfare, personal issues, and also to oversee the way that they are treated whilst they are in the prison by prison and police officers. ${ }^{94}$

Prosser also runs cultural diversity training programs for incoming police recruits in conjunction with the Aboriginal Affairs Directorate of the Department of Police. Prosser credits much of his position as an advocate for Aboriginal rights to his Army experience.

Prosser's tenure in the Army coincided with the period of activism during which Indigenous and non-Indigenous people challenged not only their status within Australia, but also the very notion of assimilation. The challenges forced governments, political parties and organisations purporting to support Indigenous advancement to reshape their own conceptions of assimilation, accepting the importance of Aboriginal people retaining their cultural distinctiveness. By the late 1960s integration had replaced assimilation as the preferred model, and the early 1970s ushered in calls for self-determination. ${ }^{95}$ Exiting the armed forces in the self-determination era gave Prosser opportunities that previous servicemen such as Grant and Saunders did not have. Prosser summarises how the Army set him up:

The armed services gave you equality, it gave you respect and it gave you the opportunity for advancement, which are some of the things that a lot of my people that were living in the "normal world", brackets on, brackets off, never got in terms of white society. I was an equal; I was on equal terms. ${ }^{96}$

\section{Conclusion}

Douglas Grant, Reg Saunders and Phil Prosser are high-profile Aboriginal exservicemen. Their life stories vary across their individual circumstances, but what links them is how military service gave them equality, contributed to their leadership skills and led them to fight for Aboriginal equality in civilian Australia. What also unites them is how white Australia - whether through

94 NLA TRC 5000/183.

95 McGregor 2011: 98-118; Haebich 2008: 377-389; Clark 2008: 99-105; Attwood 2003: 193-211;

96 Phil Prosser, in The Forgotten 2003. 
the media or government propaganda - tried to paint them as assimilation 'success' stories. They navigated difficult paths, flirting with multiple visions of assimilation. Despite white Australia's efforts to define them, each of them trod their own paths. They all embraced versions of assimilation that aligned with the contemporaneous discourses, all in search of the equality that they experienced in the armed forces. Ultimately upon re-evaluating their own situations they recognised the disconnect between assimilation propaganda and their lived experiences of inequality.

Though Grant, Saunders and Prosser had profiles in the media, they were of course not the only Indigenous ex-servicemen and women who confronted the challenges of assimilation. Life stories of other Aboriginal ex-service personnel such as Second World War veterans Oodgeroo Noonuccal (formerly Kath Walker), Stewart Murray and Lambert McBride, and Vietnam veteran Glenn James reveal common sentiments. ${ }^{97}$ Two of Oodgeroo's poems entitled 'Assimilation - No!' and 'Integration - Yes!' effectively encapsulate those sentiments. In 'Integration - Yes!' she writes:

We would like to see

Our own customs kept, our old

Dances and songs, crafts and corroborees.

Why change our sacred myths for your sacred myths?

No, not assimilation but integration,

Not submergence but our uplifting,

So black and white may go forward together

In harmony and brotherhood..$^{98}$

Perhaps it is fitting to let Reg Saunders have the last word: 'It isn't easy being a black Australian, but I wouldn't want it any other way.... And I've certainly never consciously regretted the fact that I wasn't born white'.$^{99}$

97 See Hall 1995: 111-133; Cochrane 1994; Gilbert 1977: 76-78; McBride 2000; James 2001.

98 Oodgeroo 1990: 22.

99 Saunders, in Gordon 1965: 19. 
ABORIGINAL HISTORY 2014 VOL 38

\section{References}

\section{Archival sources}

AWM S00520, Reginald Walter Saunders, interview with Peter Read for the Keith Murdoch Sound Archive of Australia in the war of 1939-45, 13 January 1989, Australian War Memorial, Canberra.

ML MSS 2766, Mitchell Library, Sydney

National Australian Archives

NAA Canberra, series A659, item 1939/1/12995

NAA Canberra, series A659, item 1942/1/3043

NAA Canberra, series B2455, item GRANT D.

NAA Canberra, series B2458, item 337678: SAUNDERS, Reginald Walter

NAA Melbourne, series B337, item 664

NAA Melbourne, series B1535, item 849/3/1644

NAA Melbourne, series B1535, item 929/19/912

NAA Melbourne, series MP508/1, item 82/712/670

NAA Melbourne, series MP508/1, item 240/701/217

NAA Melbourne, series MP508/1, item 275/750/1310

NAA Sydney, series C138, item R70396 DOUGLAS GRANT

'The Story of Douglas Grant, the Black Scotsman' 1957, presented by John Thompson and Brian Hungerford, ABC Radio, Script available from NAA Sydney, series SP1297/2, item 12912078.

\section{National Library of Australia}

NLA MS 9058, Papers of Douglas Grant, 1918-1988 [manuscript], created by Michael Cigler.

NLA TRC 5000/183, Phillip Prosser, interview with John Bannister, 'Bringing Them Home Oral History Project', Perth, 22 January 2000.

Newspapers and magazines

The Advertiser (Adelaide) 
Advocate (Burnie, Tasmania)

The Argus (Melbourne)

The Australian Museum Magazine

Brisbane Courier

Cairns Post

The Capricornian (Rockhampton, Queensland)

The Daily News (Perth)

Dawn

Gippsland Times

The Mail (Adelaide)

Melbourne Herald

The Mercury (Hobart)

Morning Bulletin (Rockhampton, Queensland)

The Northern Miner (Charters Towers, Queensland)

Portland Guardian

The Register (Adelaide)

The Register News-Pictorial (Adelaide)

The Sydney Morning Herald

Townsville Daily Bulletin

The West Australian

Western Mail (Perth)

\section{Published sources}

Attwood, Bain 2003, Rights for Aborigines, Allen \& Unwin, Crows Nest, New South Wales.

Australia, Senate, Community Affairs Reference Committee 2004, Forgotten Australians: A report on Australians who experienced institutional or out-of-home 
care as children, available online from http://www.aph.gov.au/senate/ committee/clac_ctte/completed_inquiries/2004-07/inst_care/report/ (accessed 5 November 2010).

Clark, Jennifer 2008, Aborigines \& Activism: Race, Aborigines \& the Coming of the Sixties to Australia, University of Western Australia Press, Crawley.

Cochrane, Kathie 1994, Oodgeroo, University of Queensland Press, St Lucia.

Elkin, AP 1944, Citizenship for the Aborigines: A National Aboriginal Policy, Australasian Publishing Co, Sydney.

The Forgotten 2003, directed by Glen Stasiuk, originally aired as an episode of Message Stick on the Australian Broadcasting Corporation (ABC), 27 April 2003, videocassette.

Gilbert, Kevin 1977, Living Black: Blacks Talk to Kevin Gilbert, Allen Lane, The Penguin Press, Ringwood, Victoria.

Gordon, Harry 1965, The Embarrassing Australian: The Story of an Aboriginal Warrior, Cheshire-Lansdowne, Melbourne.

Grimshaw, Peter 1992, 'Captain Reg Saunders, MBE: an Aboriginal warrior and Australian soldier', Aboriginal History 16(1): 85-98.

Haebich, Anna 2005, ‘Nuclear, suburban and black: Middleton's vision of assimilation', in Tim Rowse (ed), API Network, Perth: 201-220.

- 2008, Spinning the Dream: Assimilation in Australia, 1950-1970, Fremantle Press, Perth.

Hall, Robert 1995, Fighters from the Fringe: Aborigines and Torres Strait Islanders Recall the Second World War, Aboriginal Studies Press, Canberra.

- 1997, The Black Diggers: Aborigines and Torres Strait Islanders in the Second World War, 2nd edition, Aboriginal Studies Press, Canberra.

Huggonson, David 1993, 'Aboriginal diggers of the 9th Brigade, First AIF', Journal of the Royal Australian Historical Society 79: 214-225.

Jackomos, Alick and Derek Fowell (eds) 1993, Forgotten Heroes: Aborigines at War from the Somme to Vietnam, Victoria Press, Melbourne.

James, Glenn 2001, interview with Ina Bertrand, Templestowe, Victoria, 23 January 2001, Victorians at War - Oral History Project, http://www. victoriansatwar.net/archives/james.html (accessed 18 February 2013). 
Janowitz, Morris 1976, 'Military institutions and citizenship in Western societies', Armed Forces and Society 2(2): 185-204.

Kerin, Rani 2011, Doctor Do-Good: Charles Duguid and Aboriginal Advancement, 1930s-1970s, Australian Scholarly Publishing, North Melbourne.

Lucy, Niall 1988, 'Douglas Grant 1885-1951: Aboriginal soldier', in Unsung Heroes $\mathcal{E}$ Heroines of Australia, Suzy Baldwin (ed), Greenhouse Publications, Elwood, Victoria: 148-150.

Manning, Corinne 2005, "“If aborigines are to be assimilated they must learn to live in houses": Victoria's transitional Aboriginal housing policy', in Contesting Assimilation, Tim Rowse (ed), API Network, Perth: 221-235.

Maynard, John 2005, 'The other fellow: Fred Maynard and the 1920s defence of cultural difference', in Contesting Assimilation, Tim Rowse (ed), API Network, Perth: 27-38.

- 2007, Fight for Liberty and Freedom: The Origins of Australian Aboriginal Activism, Aboriginal Studies Press, Canberra.

McBride, Stan 2000, in They Spoke Out Good: Indigenous Elders tell their stories of struggle and achievement, proceedings of forum, 18 November 1999, Nundah Reconciliation Group, Wavell Heights North, Queensland: 18-20.

McGregor, Russell 2011, Indifferent Inclusion: Aboriginal People and the AustralianNation, Aboriginal Studies Press, Canberra.

- 2007, 'Making one people: whiteness, Australian nationhood and Aboriginal assimilation', in Historicising Whiteness: Transnational Perspectives on the Construction of an Identity, Leigh Boucher, Jane Carey and Katherine Ellinghaus (eds), RMIT Publishing in association with the School of Historical Studies, University of Melbourne, Melbourne: 71-79.

Mickler, Steve 1998, The Myth of Privilege: Aboriginal Status, Media Visions, Public Ideas, Fremantle Arts Centre Press, Perth.

Moodie, David 1989, 'Soldier Saunders', The Australian Way, April: 14-17.

Murray, Suellen, John Murphy, Elizabeth Branigan and Jenny Malone 2008, After the Orphanage: Life Beyond the Children's Home, University of New South Wales Press, Sydney.

Oodgeroo Noonuccal 1990, My People, 3rd edition, The Jacaranda Press, Milton, Queensland. 


\section{ABORIGINAL HISTORY 2014 VOL 38}

Pottinger, Paul 2000, 'The Unknown Soldier', The Australian Magazine, 4 November: 30-36.

Pratt, Rod 2007, 'Queensland's Aborigines in the First Australian Imperial Force', in Aboriginal Peoples and Military Participation: Canadian E International Perspectives, P Whitney Lackenbauer, R Scott Sheffield and Craig Leslie Mantle (eds), Canadian Defence Academy Press, Kingston, ON: 215-236.

Ramsland, John and Christopher Mooney 2006, Remembering Aboriginal Heroes: Struggle, Identity and the Media, Brolga Publishing Pty Ltd, Melbourne.

Riseman, Noah 2011, 'The Stolen Veteran: institutionalisation, military service and the Stolen Generations', Aboriginal History 35: 57-77.

- 2012, 'Equality in the ranks: the lives of Aboriginal Vietnam veterans', Journal of Australian Studies 36(4): 411-426.

- 2013a, 'Racism, Indigenous people, and the Australian armed forces in the post-Second World War era', History Australia 10(2): 159-179.

- 2013b, 'Serving their country: a short history of Aboriginal and Torres Strait Islander service in the Australian Army', Australian Army Journal X(3): 11-22.

Rowse, Tim 2005, 'Introduction: Contesting Assimilation', in Contesting Assimilation, Tim Rowse (ed), API Network, Perth: 1-24.

Scott, Kim and Hazel Brown 2005, Kayang \& Me, Fremantle Arts Centre Press, Fremantle.

Swain, Shurlee and Margot Hillel 2010, Child, Nation, Race and Empire: Child Rescue Discourse, England, Canada and Australia, 1850-1915, Manchester University Press, Manchester.

Thomson, Alistair 2006, 'Anzac stories: using personal testimony in war history', War $\mathcal{E}$ Society 25(2): 1-21.

- 2013, ANZAC Memories: Living with the Legend, 2nd edition, Monash University Publishing, Melbourne.

Wadham, Ben 2013, 'BROTHERHOOD', Australian Feminist Studies 28(76): 212235.

Wells, Julie and Michael Christie 2000, 'Namatjira and the burden of citizenship', Australian Historical Studies 31(114): 110-130.

Winegard, Timothy 2012, Indigenous Peoples of the British Dominions and the First World War, Cambridge University Press, Cambridge. 
This text taken from Aboriginal History, Volume 38, edited by Shino Konishi, published 2015 by

ANU Press, The Australian National University, Canberra, Australia. 